chemistry at the University of Glasgow under Thomas Thomson, graduated M.A. in 1824, and in 1830 became professor of chemistry at the Andersonian College. In 1837 he was appointed to the chair of chemistry at University College, London, and in 1855 he succeeded Sir John Herschel as Master of the Mint. Graham's name is attached to a tube plugged at one end with plaster of paris, which he used in his experiments on the molecular diffusion of gases (1829-31), and to his famous law. Separating animal and other fluids by dialysis, he distinguished between colloids and crystalloids; he also established the polybasic nature of phosphoric acid and noted the formation with alcohol of certain salts, which he called alcoates and which he observed to be analogous to hydrates. Graham possessed a lively mind, though his body was feeble, and he led a full and busy life. He was vice-president of the chemical jury at the Great Exhibition of 1851 and assisted in various inquiries ranging from the ventilation in the House of Commons and London's water supply to methods of gun-casting. At the age of thirty-one he was elected a Fellow of the Royal Society and was awarded Royal Medals in 1838 and 1850 . In 1840 he became the first president of the Chemical Society, which he had helped to found, and six years later first president of the Cavendish Society. His "Elements of Chemistry" (1842) was long a classic. Graham died on September 11, 1869, at the age of sixty-four.

\section{Gregor Johann Mendel}

Prof. E. O. Dodson, of the University of Notre Dame, United States, has been fortunate enough to obtain a transcript of material on the life and work of Mendel taken from the archives of Mendel's monastery and of the Augustinian Order in Rome. The material was collected during the 1930 's under the direction of the Right Rev. F. W. Howard, Bishop of Covington, Kentucky, and was entrusted by him to Sister M. Julitta, of Villa Madonna College (Scientific Monthly, 81, No. 4 ; October 1955). Using this material, Prof. Dodson has compiled a fascinating account of Mendel's early life and education, his training and monastic work in the monastery of Brünn, his election as abbot, and his unswerving endeavours to discover natural laws. The article also throws new light on the rediscovery of Mendel's work by de Vries, Correns and von Tschermak.

\section{Noise, Vibration and Health}

Is the House of Commons on December 2, Sir Lionel Heald introduced a debate on the effect of noise and vibration on the health, well-being and efficiency of the nation, and urged the Government to give careful attention to research and education in this field, and to the need for more effective measures for the protection of the public. Tribute was paid by Sir Lionel, and by other speakers, to the immense amount of work which has been done in this field by the Building Research Station, and, on the medical side, by Dr. Littler and others at King's College Hospital ; but it was urged that full advantage is not being taken of available knowledge. Mr. R. Bell, in seconding the motion, besides directing attention to the scope for administrative action and the need for some amendment of the law, suggested that Ministers responsible for departments which are the main offenders should insist on departmental programmes of research and education, and in particular urged that the definition of noise should replace vague terms such as 'reasonable and practicable'. Replying for the Government, the Joint Under-Secretary of State for the Home Department, Sir Hugh Lucas-Tooth, agreed that responsibility must rest with individual departments, and he advised the House to accept the motion. The control of exhaust noise from motor-vehicles is partly in the hands of the police, with whom man-power is a major difficulty, and partly a technical problem between the Ministry and the manufacturers. As regards aircraft, a new principle embodied in the Conway engine is claimed to effect a further reduction in noise, and in the view of the Minister of Supply, technical effort in this field should be directed to the problem in connexion with new types of aircraft. Sir Hugh also referred to the study of vibration caused by passing aircraft, undertaken by the Building Research Station, to the attention being given to the prevention of noise in hospitals and to the investigations of the effect of noise in factories made by the Industrial Health Research Board.

\section{Thermonuclear Explosions}

Following the broadcast from Moscow reported in the press that Soviet Russia is willing to discontinue hydrogen bomb tests by common agreement, the Government has been repeatedly questioned in the House of Commons on the subject. On November 30, in reply to Mr. Attlee, the Prime Minister stated that the Government had had no communication on the subject from the Soviet Government, but was ready to discuss these matters at any time. Sir Anthony commented that the reported statement might have appeared in a better light if it had been made before the recent Soviet explosion, and added that in any such discussions regard would have to be paid to the number and nature of the tests which each country had already made, as well as to those proposed. He also said that it remained the view of the British Government that a comprehensive disarmament agreement is the only final solution to these problems. When pressed by Mr. Attlee on that day, the Prime Minister did not, however, deal with the fundamental reason causing concern over the continuance of such tests, namely, the possible biological effects of the resultant radiation, or with the fact that no system of inspection is necessary to ensure that thermonuclear tests are not made in spite of undertaking to discontinue them, because such explosions can be detected over a wide area. These points were raised on December 1 in a question asking the Prime Minister to propose to President Eisenhower and Marshal Bulganin a cessation of all nuclear explosions pending the report of the United Nations Commission which is considering the effects of radiation. There was also on the notice paper a motion regretting the continuance of such tests, and expressing the belief that the tests in themselves involve a danger to the human race and requesting the Government not to proceed with such tests. On December 6, in reply to further questions, the Prime Minister suggested that we should await the report on nuclear radiation from the Medical Research Council, which is expected within two or three months, and also one from the United States National Academy of Sciences. He also said that the Government has no intention of departing from its decision to manufacture the hydrogen bomb, and it still regards manufacture and possession of the hydrogen bomb as a deterrent to war. While willing to discuss methods of regulating and limiting test 